\title{
Maternal Vitamin D Levels in Gestation - An Observational Cross Sectional Study in the Rural Population of South India
}

\author{
Julie Christy Amalraj ${ }^{* 1}$, Andal ${ }^{2}$, Perumal Saraswathi ${ }^{3}$, Swayam Jothi Dorairaj ${ }^{4}$, Dr. G. Sumathy ${ }^{5}$ \\ ${ }^{1} \mathrm{PhD}$ Scholar, Bharath University, (BIHER) Seliyur, Tambaram, Chennai \\ ${ }^{2}$ Associate Professor, Department of Obstertics and Gynaecology Shri SathyaSai Medical College an Hospital, Sri Balaji \\ Vidyapeeth University (SBV) Deemed to be University, Ammapettai, Nellikuppam, Kachipuram 603108 \\ ${ }^{3}$ Emeritus professor of Anatomy, Tamil Nadu DR. M.G.R Medical University, Guindy, Chennai \\ ${ }^{4}$ Professor, Department of Anatomy, Shri SathyaSai Medical College and Research Institute, Sri Balaji Vidyapeeth \\ University (SBV) Deemed to be University, Ammapettai, ThiruporurGuduvancherryRoad, Kancheepuram 6030108 \\ ${ }^{5}$ Professor and Head Department of Anatomy, Sri Balaji Dental College and Hospital, Chennai
}

Corresponding Author: Dr. A. Julie Christy; drjuliechristy@gmail.com

Received 02 August 2019;

Accepted 13 August 2019;

Published 29 August 2019

\begin{abstract}
Background:Vitamin D* called the sunshine vitamin is essential throughout life. Pregnancy is an altered physiological state in women, which requires proper nourishment. During gestation, this vitamin also plays an important role in development of the fetus. Objective: To observe the serum vitamin D (25diohydroxycholicalciferol) levels and serum calcium levels in the maternal blood during the three trimesters. Design: Observational Cross sectional study. Study population: Rural Mothers from Kancheepuram District, Tamil Nadu South India. We used 50 antenatal blood samples as experimental group and 15 as control group. The age group included 20-40 years. Blood samples were collected from 50 antenatal mothers between 20 - 40 years age group, from Obstetrics and Gynecology OPD for their routine antenatal check-ups, after getting duly signed informed consent. Control group had 15 women in the same age group not pregnant. Results: The results were tabulated. The mean value of 25dihydroxy vitamin D was observed very low than normal levels in all the three trimesters. The mean value of serum vitamin D in first trimester was $50.87 \mathrm{ng} / \mathrm{ml}$, mean value of serum vitamin D in second trimester was $54.05 . \mathrm{ng} / \mathrm{ml}$, and mean third trimester vitamin D was $61.24 \mathrm{ng} / \mathrm{ml}$ which was well below the optimum level of $100 \mathrm{ng} / \mathrm{ml}$. Conclusion: The vitamin D deficiency with normal level maintenance of serum calcium shows the compensatory mechanism that involves the normal calcium level maintence with resorption of bones by the osteoclastic actions to correct the deficit. If the deficiency is left untreated it may lead to faster osteoporosis in the mother.
\end{abstract}

*25 dihydroxycholicalciferol

Keywords: Maternal, Vitamin D, First trimester, Second trimester, Third trimester, Serum Calcium

\section{Introduction}

$80 \%$ of the vitamin is synthesized from the sunlight sources and remaining 20\% from dietary sources (Kamal AS shoumer A, 2015).Vitamin D is a vitamin with primary source from the sunlight. Being a fat soluble vitamin with cholesterol structure vitamin $\mathrm{D}$ is produced from the 7-hydroxycholesterol (subcutaneous fat) on exposure to sunlight. Vitamin D is therefore not a real vitamin. Safe sunlight exposure or consumption of food stuffs artificially supplemented with vitamin D is necessary (Kamal AS 2015, ChihChien Sung 2012) 7 Hydroxycholesterol is stored in the liver and activated whenever demand arises. The fetus depends on the maternal supply of vitamin D, calcium, and phosphorus, which is transmitted across the placenta. In fact, maternal and cord blood 25-hydroxyvitamin D $(25[\mathrm{OH}] \mathrm{D})$ are highly correlated in terms of supporting the importance of this vitamin for fetal development (ChihChien Sung 2012). Vitamin D deficiency has been reported as a common problem worldwide. Vitamin D deficiency [defined as $25(\mathrm{OH}) \mathrm{D}<30 \mathrm{n} \mathrm{mol} / \mathrm{L}$ according to the Institute of Medicine (National Academy of Sciences, Washington, D.C., USA)] or inadequacy [25(OH)D of 30-49.9 $\mathrm{n} \mathrm{mol} / \mathrm{L}]$, but the RDA for tropical countries has not been determined. RDA of this vitamin differs based on the sunlight exposure, climatic changes (Xiao J-P, Zang J,2015). Deficiency during gestation is more acute. The vitamin deficiency not only affects the mother but also the foetus. The study focuses on the vitamin D levels in various 
trimesters of pregnancy. The compensatory mechanism involved in maintaining the serum calcium levels normal despite there is deficiency of vitamin D.

\section{Materials and methods}

Vitamin D levels (serum 25 dihydroxycholicalciferol) were estimated from venous blood samples of 15 antenatal women of first, second, third trimester each and in 15 non pregnant women. 60 venous blood samples got from Obstertics and Gynaecology Outpatient department of Ponniayah Ramajayam Institute of Medical Sciences, Kancheepuram were used for the study. The blood samples were collected after getting ethical clearance and institutional review board permission from the institution (PRIMS/IEC-certi-002/16.02.2018) The mothers involved in the study were informed about the study and written consent was got from the participants. The blood collected for routine procedures was used for the assessment of the vitamin D levels.

The participants were dark pigmented, with considerable outdoor activities. Tamil Nadu in India has tropical climatic conditions with sufficient sunlight exposure. The samples were collected from January - May. Life style, food habits were accessed with questionnaires.The participants were not on supplementation for nutrients except iron and folic acid. Most of the patients were unaware of their vitamin D status. All the participants predominantly had rice based diet. The BMI was observed to be on the higher side

\section{Exclusion criteria}

Mothers with chronic infections, diabetes, hypertension, epileptic (seizures), multiple gestations were not included in the study.

Study Type: Observational Cross Sectional Study

Sample Size: 60 samples

\section{Method}

Under aseptic conditions $5 \mathrm{ml}$ of venous blood from antenatal mothers were taken during their routine checkup. The blood collected was centrifuged and serum was separated using REMI 250-300 RPM/per minute. The sample was centrifuged for 3 minutes. The serum was utilized for estimation of vitamin D. The vitamin D estimation was done in Vimta labs pvt limited Chennai. The estimation was done using Chemiluminescence (CLIA) method

\section{Observations}

\section{First Trimester}

The value of serum $25 \mathrm{OH}$ Cholicaliciferol in venous blood samples was observed to be lower than $30 \mathrm{nmol} / \mathrm{L}(12 \mathrm{ng} / \mathrm{ml})$ in most of the peripheral blood samples. The mean of 25 dihydroxycholicalciferol level and serum calcium was calculated. The mean vitamin D level was insufficient in the first trimester, gradually increased in second trimester and in the third trimester. The serum calcium levels were found to be normal in all the trimesters while the vitamin D (25 hydroxy vitamin D) was recorded insufficient. Vitamin D insufficiency was not affecting the serum calcium levels in the patients. (Table 1)(Anne Marie Uwitoze et al 2018, BrittevanWeert 2015 et al, Souberbielle JC 2010 et al)

In first trimester the mean serum vitamin $\mathrm{D}$ was $50.86 \mathrm{ng} / \mathrm{ml}$.

\section{Second Trimester}

The mean value recorded was $54.05 \mathrm{ng} / \mathrm{ml}$ the values were slightly higher in second trimester when compared to the first trimester. The values recorded were still lower than the optimal 25 dihydroxyvitamin $\mathrm{D}$ values recommended as dietary allowance. (Table 2)

\section{Third Trimester}

The mean value of third trimester serum 25 dihydroxy vitamin $D$ is $64 \mathrm{ng} / \mathrm{ml}$. This has progressively increased from second trimester to third trimester. There is gradual increase in the 25 dihydroxyvitamin $\mathrm{D}$ in the third trimester. While the serum calcium levels were maintained normal. Third trimester has reported a gradual increase in the serum vitamin D levels when compared to first and second trimester.(Table 3)

\section{Control Samples}

The mean vitamin D levels in control sample were $56.85 \mathrm{ng} / \mathrm{ml}$. The control sample was taken from non-pregnant women from second to fifth decade of life. (Table 4)

Table 1: Tabulation of serum calcium and vitamin D values estimated by Chemiluminescence (CLIA) 25 dihydroxy vitamin D has been discussed in terms of $\mathrm{ng} / \mathrm{ml}$

[2.5 nmol/L 25(OH)D $=1 \mathrm{ng} / \mathrm{mL25}(\mathrm{OH}) \mathrm{D}]$. In first, second and third trimester

SI Units: < $50 \mathrm{nmol} / \mathrm{L}$ - Deficient 50 - < $75 \mathrm{nmol} / \mathrm{L}$ - Insufficient 75 - $250 \mathrm{nmol} / \mathrm{L}$ - Sufficient > $250 \mathrm{nmol} / \mathrm{L}$ - Upper Safety Limit

\begin{tabular}{|l|l|l|l|l|l|}
\hline Pt.id* & Age & Serum Calcium & Vitamin D & Gestation weeks & Levels in SI units interpretation \\
\hline 1 & $24 / \mathrm{F}$ & $7 \mathrm{mg} / \mathrm{dl}$ & $56.25 \mathrm{ng} / \mathrm{ml}$ & 9 weeks 2 days & Insufficient \\
\hline 2 & $21 . \mathrm{f}$ & $6.5 \mathrm{mg} / \mathrm{dl}$ & $59.5 \mathrm{ng} / \mathrm{ml}$ & 15 weeks & Insufficient \\
\hline 3 & $28 / \mathrm{f}$ & $10 \mathrm{mg} / \mathrm{dl}$ & $52 \mathrm{ng} / \mathrm{ml}$ & 12 weeks & Insufficient \\
\hline 4 & $28 / \mathrm{F}$ & $8.2 \mathrm{mg} / \mathrm{dl}$ & $44.25 \mathrm{ng} / \mathrm{ml}$ & 11 weeks 4 days & Deficient \\
\hline 5 & $24 / \mathrm{F}$ & $7 \mathrm{mg} / \mathrm{dl}$ & $34.75 \mathrm{ng} / \mathrm{ml}$ & 12 weeks 4 days & Deficient \\
\hline 6. & $25 / \mathrm{F}$ & $7.8 \mathrm{mg} / \mathrm{dl}$ & $55.5 \mathrm{ng} / \mathrm{ml}$ & 10 weeks & Insufficient \\
\hline 7 & $25 / \mathrm{f}$ & $8.9 \mathrm{mg} / \mathrm{dl}$ & $51 \mathrm{ng} / \mathrm{ml}$ & 7 weeks & Insufficient \\
\hline 8 & $22 / \mathrm{F}$ & $8.3 \mathrm{mg} / \mathrm{dl}$ & $65.75 \mathrm{ng} / \mathrm{ml}$ & 11 weeks & Insufficient \\
\hline 9 & $22 / \mathrm{F}$ & $9.4 \mathrm{mg} / \mathrm{dl}$ & $54 \mathrm{ng} / \mathrm{ml}$ & 9 weeks 5 days & Insufficient \\
\hline 10 & $23 / \mathrm{F}$ & $9.2 \mathrm{mg} / \mathrm{dl}$ & $36 \mathrm{ng} / \mathrm{ml}$ & 8 weeks 2 days & Deficient \\
\hline 11 & $39 / \mathrm{F}$ & $8.6 \mathrm{mg} / \mathrm{dl}$ & $40 \mathrm{ng} / \mathrm{ml}$ & 12 weeks 6 days & deficient \\
\hline 12 & $27 / \mathrm{F}$ & $9.2 \mathrm{mg} / \mathrm{dl}$ & $46 \mathrm{ng} / \mathrm{ml}$ & 7 weeks 3 days & deficient \\
\hline 13 & $22 / \mathrm{F}$ & $8.5 \mathrm{mg} / \mathrm{dl}$ & $62 \mathrm{ng} / \mathrm{ml}$ & 8 weeks & insufficient \\
\hline 14 & $22 / \mathrm{F}$ & $8.8 \mathrm{mg} / \mathrm{dl}$ & $42 \mathrm{ng} / \mathrm{ml}$ & 9 weeks & deficient \\
\hline 15 & $27 / \mathrm{F}$ & $9.1 \mathrm{mg} / \mathrm{dl}$ & $64 \mathrm{ng} / \mathrm{ml}$ & 11 weeks & insufficient \\
\hline
\end{tabular}


Mean serum vitamin D: $50.87 \mathrm{ng} / \mathrm{ml}$

First Trimester: Deficient $-40 \%$ of the first trimester mothers

Insufficient $-60 \%$ of the first trimester mothers

Table 2: Serum vitamin $d$ and calcium observed in second trimester tabulated.

SI Units: < $50 \mathrm{nmol} / \mathrm{L}$ - Deficient 50 - < $75 \mathrm{nmol} / \mathrm{L}$ - Insufficient 75 - $250 \mathrm{nmol} / \mathrm{L}$ - Sufficient > $250 \mathrm{nmol} / \mathrm{L}$ - Upper Safety Limit

\begin{tabular}{|c|c|c|c|c|c|}
\hline \multirow[b]{2}{*}{ Pt.id } & \multicolumn{4}{|c|}{ SECOND TRIMESTER } & \multirow[b]{2}{*}{ Levels in SI units interpretation } \\
\hline & Age & Gestation in weeks & Serum calcium & Vitamin D & \\
\hline 1 & $23 / \mathrm{F}$ & 22 weeks & $9.7 \mathrm{mg} / \mathrm{dl}$ & $55 \mathrm{ng} / \mathrm{ml}$ & Insufficient \\
\hline 2 & $24 / \mathrm{F}$ & 24 weeks & $9.9 \mathrm{mg} / \mathrm{dl}$ & $65 \mathrm{ng} / \mathrm{ml}$ & insufficient \\
\hline 3 & $24 / \mathrm{f}$ & 23 weeks & $9.8 \mathrm{mg} / \mathrm{dl}$ & $56 \mathrm{ng} / \mathrm{ml}$ & insufficient \\
\hline 4 & $26 / f$ & 24 weeks & $8 \mathrm{mg} / \mathrm{dl}$ & $49.75 \mathrm{ng} / \mathrm{ml}$ & deficient \\
\hline 5 & $23 / f$ & $\begin{array}{l}28 \text { weeks } \\
4 \text { days }\end{array}$ & $9.8 \mathrm{mg} / \mathrm{dl}$ & $54.25 \mathrm{ng} / \mathrm{ml}$ & insufficient \\
\hline 6 & $27 / f$ & $\begin{array}{l}18 \text { weeks } \\
3 \text { days }\end{array}$ & $9 \mathrm{mg} / \mathrm{dl}$ & $51 \mathrm{ng} / \mathrm{ml}$ & insufficient \\
\hline 7 & $27 / f$ & 27 weeks & $9.8 \mathrm{mg} / \mathrm{dl}$ & $68 \mathrm{ng} / \mathrm{ml}$ & insufficient \\
\hline 8 & $27 / f$ & 19 weeks & $8.3 \mathrm{mg} / \mathrm{dl}$ & $31 \mathrm{ng} / \mathrm{ml}$ & deficient \\
\hline 9 & $20 / f$ & $\begin{array}{l}20 \text { weeks } \\
5 \text { days }\end{array}$ & $8.6 \mathrm{mg} / \mathrm{dl}$ & $42 \mathrm{ng} / \mathrm{ml}$ & deficient \\
\hline 10 & $24 / f$ & 17 weeks & $9.3 \mathrm{mg} / \mathrm{dl}$ & $62 \mathrm{ng} / \mathrm{ml}$ & insufficient \\
\hline 11 & $29 / f$ & 16 weeks & $9.8 \mathrm{mg} / \mathrm{dl}$ & $81.1 \mathrm{ng} / \mathrm{ml}$ & sufficient \\
\hline 12 & $28 / \mathrm{F}$ & 14 days & $9.5 \mathrm{mg} / \mathrm{dl}$ & $44.25 \mathrm{ng} / \mathrm{ml}$ & deficient \\
\hline 13 & $24 / \mathrm{F}$ & $\begin{array}{l}16 \text { weeks } \\
4 \text { days }\end{array}$ & $8.4 \mathrm{mg} / \mathrm{dl}$ & $34.75 \mathrm{ng} / \mathrm{ml}$ & deficient \\
\hline 14 & $25 / \mathrm{F}$ & 17 weeks 2 days & $8.1 \mathrm{mg} / \mathrm{dl}$ & $51 \mathrm{ng} / \mathrm{ml}$ & insufficient \\
\hline 15 & $22 / \mathrm{F}$ & 20 weeks & $9.5 \mathrm{mg} / \mathrm{dl}$ & $65.75 \mathrm{ng} / \mathrm{ml}$ & insufficient \\
\hline
\end{tabular}

Mean serum vitamin D in second trimester $54.05 \mathrm{ng} / \mathrm{ml}$

Deficient $-33.3 . \%$ of the second trimester mothers

Insufficient $-60 \%$ of the second trimester mothers

Sufficient $-6.7 \%$ of the second trimester mothers

Table 3: Serum vitamin $D$ and serum calcium observed in third trimester tabulated

SI Units: < $50 \mathrm{nmol} / \mathrm{L}$ - Deficient 50 - < $75 \mathrm{nmol} / \mathrm{L}$ - Insufficient 75 - $250 \mathrm{nmol} / \mathrm{L}$ - Sufficient > $250 \mathrm{nmol} / \mathrm{L}$ - Upper Safety Limit

\begin{tabular}{|l|l|l|l|l|l|}
\hline \multicolumn{7}{|l}{ THIRD TRIMESTER } & calcium & Vitamin D & Levels in SI units interpretation \\
\hline Pt.id & Age/sex & Gestation in weeks & $8.9 \mathrm{mg} / \mathrm{dl}$ & $15.25 \mathrm{ng} / \mathrm{ml}$ & Deficient \\
\hline 1 & $28 / \mathrm{F}$ & 35 weeks 3 days & $9 \mathrm{mg} / \mathrm{dl}$ & $59.9 \mathrm{ng} / \mathrm{ml}$ & Insufficient \\
\hline 2 & $20 / \mathrm{f}$ & 32 weeks & $7.8 \mathrm{mg} / \mathrm{dl}$ & $29 \mathrm{ng} / \mathrm{ml}$ & deficient \\
\hline 3 & $28 / \mathrm{f}$ & 29 weeks 6 days & $10.4 \mathrm{mg} / \mathrm{dl}$ & $42 \mathrm{ng} / \mathrm{ml}$ & deficient \\
\hline 4 & $22 / \mathrm{F}$ & 31 weeks 3 weeks & $11 \mathrm{mg} / \mathrm{dl}$ & $64 \mathrm{ng} / \mathrm{ml}$ & insufficient \\
\hline 5 & $27 / \mathrm{F}$ & 30 weeks 3 days & $8.7 \mathrm{mg} / \mathrm{dl}$ & $72 \mathrm{ng} / \mathrm{ml}$ & insufficient \\
\hline 6 & $20 / \mathrm{F}$ & 34 weeks & $8.2 \mathrm{mg} / \mathrm{dl}$ & $63.25 \mathrm{ng} / \mathrm{ml}$ & insufficient \\
\hline 7 & $26 / \mathrm{F}$ & 34 weeks & $7.3 \mathrm{mg} / \mathrm{dl}$ & $86.5 \mathrm{ng} / \mathrm{ml}$ & sufficient \\
\hline 8 & $21 / \mathrm{F}$ & 30 weeks & $9.4 \mathrm{mg} / \mathrm{dl}$ & $56.25 \mathrm{ng} / \mathrm{ml}$ & insufficient \\
\hline 9 & $26 / \mathrm{F}$ & 34 weeks & $10.5 \mathrm{mg} / \mathrm{dl}$ & $72.75 \mathrm{ng} / \mathrm{ml}$ & Insuffcient \\
\hline 10 & $20 / \mathrm{F}$ & 33 weeks & $11.2 \mathrm{mg} / \mathrm{dl}$ & $101.25 \mathrm{ng} / \mathrm{ml}$ & sufficient \\
\hline 11 & $39 / \mathrm{F}$ & 34 weeks 6 day & $9.5 \mathrm{mg}$ & $43.5 \mathrm{ng} / \mathrm{ml}$ & Deficient \\
\hline 12 & $22 / \mathrm{F}$ & 33 weeks 4 days & $9.3 \mathrm{mg} / \mathrm{dl}$ & $55 \mathrm{ng} / \mathrm{ml}$ & insufficient \\
\hline 13 & $24 / \mathrm{F}$ & 35 weeks & $8.2 \mathrm{mg} / \mathrm{dl}$ & $78 \mathrm{ng} / \mathrm{ml}$ & sufficient \\
\hline 14 & $26 / \mathrm{F}$ & 32 weeks 4 days & $9.4 \mathrm{mg} / \mathrm{dl}$ & $80 \mathrm{ng} / \mathrm{ml}$ & sufficient \\
\hline 15 & $28 / \mathrm{F}$ & 34 weeks & &
\end{tabular}

Mean serum vitamin D in third trimester: $61.24 \mathrm{ng} / \mathrm{ml}$

Deficient $-27 \%$

Insufficient $-46 \%$

Sufficient $-27 \%$

Table 4: Vitamin $D$ tabulation in control group -Women of the same age group as experimental group but not pregnant SI Units: < $50 \mathrm{nmol} / \mathrm{L}$ - Deficient 50 - < $75 \mathrm{nmol} / \mathrm{L}$ - Insufficient 75 - $250 \mathrm{nmol} / \mathrm{L}$ - Sufficient > $250 \mathrm{nmol} / \mathrm{L}$ - Upper Safety Limit

\begin{tabular}{|l|l|l|l|l|}
\hline Pt.id & Age & Serum calcium & Vitamin D & Levels in SI units interpretation \\
\hline 1 & $27 / \mathrm{f}$ & $9.8 \mathrm{mg} / \mathrm{dl}$ & $45.45 \mathrm{nmol} / \mathrm{L}$ & deficient \\
\hline 2 & $35 / \mathrm{f}$ & $9.3 \mathrm{mg} / \mathrm{dl}$ & $58.78 \mathrm{nmol} / \mathrm{L}$ & insuffcient \\
\hline
\end{tabular}




\begin{tabular}{|l|l|l|l|l|}
\hline 3 & $42 / \mathrm{f}$ & $8.5 \mathrm{mg} / \mathrm{dl}$ & $68.45 \mathrm{nmol} / \mathrm{L}$ & insufficient \\
\hline 4 & $33 / \mathrm{f}$ & $8.8 \mathrm{mg} / \mathrm{dl}$ & $54.93 \mathrm{nmol} / \mathrm{L}$ & insufficient \\
\hline 5 & $48 / \mathrm{f}$ & $10.3 \mathrm{mg} / \mathrm{dl}$ & $89.7 \mathrm{nmol} / \mathrm{L}$ & Sufficient \\
\hline 6 & $18 / \mathrm{f}$ & $9.6 \mathrm{mg} / \mathrm{dl}$ & $70.2 \mathrm{nmol} / \mathrm{L}$ & insufficient \\
\hline 7 & $36 / \mathrm{f}$ & $8.1 \mathrm{mg} / \mathrm{dl}$ & $60.78 \mathrm{nmol} / \mathrm{L}$ & insufficient \\
\hline 8 & $40 / \mathrm{f}$ & $10.3 \mathrm{mg} / \mathrm{dl}$ & $45 \mathrm{nmol} / \mathrm{L}$ & deficient \\
\hline 9 & $32 / \mathrm{f}$ & $11.4 \mathrm{mh} / \mathrm{dl}$ & $68 \mathrm{nmol} / \mathrm{L}$ & insufficient \\
\hline 10 & $37 / \mathrm{f}$ & $12.1 \mathrm{mg} / \mathrm{dl}$ & $76 \mathrm{nmol} / \mathrm{L}$ & sufficient \\
\hline 11 & $26 / \mathrm{F}$ & $11.8 \mathrm{mg} / \mathrm{dl}$ & $62 \mathrm{nmol} / \mathrm{L}$ & insufficient \\
\hline 12 & $23 / \mathrm{F}$ & $8.4 \mathrm{mg} / \mathrm{dl}$ & $56 \mathrm{nmol} / \mathrm{L}$ & insufficient \\
\hline 13 & $27 / \mathrm{f}$ & $9.2 \mathrm{mg} / \mathrm{dl}$ & $55 \mathrm{nmol} / \mathrm{L}$ & insufficient \\
\hline 14 & $31 / \mathrm{f}$ & $11.3 \mathrm{mg} / \mathrm{dl}$ & $42 \mathrm{nmol} / \mathrm{L}$ & deficient \\
\hline 15 & $22 / \mathrm{f}$ & $11.7 \mathrm{mg} / \mathrm{dl}$ & $44 \mathrm{nmol} / \mathrm{L}$ & deficient \\
\hline
\end{tabular}

Mean Serum Vitamin D levels: $59.75 \mathrm{nmol} / \mathrm{L}$

Control group:

$26 \%$ deficient

$60 \%$ insufficient

$13.3 \%$ sufficient

\section{Discussion}

Vitamin D deficiency is commonly observed in 5-50\% of pregnant women (Megan L. Mulligan, BA et al2010). The study brings to light the vitamin D status of women in early reproductive age group during various trimesters of gestation in and around Kanchipuram district. The mean maternal age group was 26 years. The study mainly enlightens on the early reproductive age group participants belonging to rural population of Kancheepuram district, India. The patients who were in middle and low socio economic status were included.

The samples were collected between the months of January - May 2017, when it was summer at Tamil Nadu.

The study was conducted as a public health awareness programme for rural pregnant women. Random sample selection was done.

The serum 25 hydroxyvitamin D levels were low in $80 \%$ of the population first trimester and third trimester. There is a sharp decrease in the $25(\mathrm{OH}) \mathrm{D}$ levels. This is due to the increased utilisation of vitamin D in maintaining calcium homeostasis and involving itself in development of bones (Elvira Larque, Eva Moralo2018). This may lead to development of reduced bone density in women at early ages. While during second trimester an optimum level of 50ng/l was maintained as an average.

The overall median value was $65 \mathrm{nmol} / \mathrm{L}$, while the first second and third trimester average was 55,60 and $67 \mathrm{nmol} / \mathrm{L}$ has been recorded in the studies conducted in western countries like UK. ( Lawlor DA, Wills AK2013)

\section{First Trimester}

According to Sera Ates et al the first trimester serum vitamin D levels were observed to be less than $10 \mathrm{ng} / \mathrm{ml}$ in $45 \%$ of the singleton pregnancies in reproductive age group. (Ates $\mathrm{S}$, Sevket O, et al 2016)

The vitamin D levels were also observed to be between 15$50 \mathrm{ng} / \mathrm{ml}$. Deficiencies during the developmental period remains crucial. Deficiency of vitamin D has been associated with preterm births. According to Bodnar et al 2007 and Baker et al 2010 , vitamin D deficiency in first trimester has been associated with preeclampsia. Adverse health outcomes such as preeclampsia, low birth weight, neonatal hypocalcemia, poor postnatal growth, bone fragility, and increased incidence of autoimmune diseases have been linked to low vitamin D levels during pregnancy and infancy.( Megan L. Mulligan, BA et al 2010)According to Li N et al (2017)25 (OH) deficiencyhas also been associatedwith recurrent miscarriages at fetal maternal interface ( $\mathrm{Li} \mathrm{N}, \mathrm{Wu} \mathrm{HM}$ et al 2017). $\mathrm{Li} \mathrm{N}$ et al also states that the decidua tissues collected during the abortion procedure had $25(\mathrm{OH}) \mathrm{D}$ deficiency, IL- 17, TGF beta, IL- 23 was estimated to be deficient in recurrent spontaneous abortion cases. ( Li N,Wu HM et al 2017).

According to Specker B in 2004 High maternal levels of $1,25(\mathrm{OD}) 2 \mathrm{D}$ is essential to increase intestinal calcium absorption during pregnancy and to support calcium for maternal and foetal metabolism

\section{Second Trimester}

This study reports mean vitamin D level of $55 \mathrm{ng} / \mathrm{ml}$ was observed in south Indian rural pregnant women during second trimester.According to Xiao J-P et al in 2015 the mean serum vitamin D levels among Chinese pregnant women in second trimester was $35 \mathrm{ng} / \mathrm{ml}$.

The mean value in Chinese pregnant women in second trimester remains at the deficient limit and it has been recorded low due to the seasonal variations and dress code etc. In comparison the median serum vitamin D in Indian pregnant women population is recorded more than the Chinese population due to the tropical climatic conditions.

\section{Third Trimester}

Significant changes occur in maternal vitamin D and calcium metabolism during pregnancy to provide calcium needed for fetal bone mineral accretion. The calcium is made available to the developing fetus from the maternal serum levels. The study reports a median value of $61 \mathrm{ng} / \mathrm{ml}$ in the third trimester pregnant women. According to Thomas D et al in 2011 the mean serum vitamin D values were less $48 \mathrm{nmol} / \mathrm{L} \quad(19.2 \mathrm{ng} / \mathrm{ml})$. The longitudinal assessment of the serum vitamin $\mathrm{D}$ levels indicate that the serum vitamin D levels were very low in first trimester and it progressively increased in second trimester and the third trimester reports the peak of the recorded values, though values reported were within deficient range.

According to Bonny Specker approximately 25-30 g of calcium are transferred to the foetus for skeletal development, most of which is transferred during the last trimester.( Bonny Specker 2004) It has been estimated that $250 \mathrm{mcg} / \mathrm{d}$ calcium is sent to the foetus during third trimester (Widdowson EM 1981). The requirement for serum calcium levels increases in the third trimester. The normal level is maintained by increased intestinal absorption, reabsorption and 
bone demineralization. Mothers with acute vitamin D deficiency have normal calcium levels by the compensatory mechanism of the body. In order to maintain normal serum calcium levels bone osteoclastic activity increases leading to osteoporosis in earlier ages in women (Bonny specker et al 2004)

The compensatory mechanism can lead to secondary hyperparathyroidism in mothers due to increase in parathromone.

The results of the longitudinal study by Y Agudelo-Zapata et al.in 2018 reports the lowest median serum vitamin D levels reported in first trimester, increased in second trimester and in third trimester it graduallyincreased based on the limits in gestational demand(Augdelo Zapata at al)

On comparing the control group women with experimental group the mean $25 \mathrm{OHD}$ levels in non-pregnant women were $31.9 \mathrm{ng} / \mathrm{mL}$ and $34.9 \mathrm{ng} / \mathrm{mL}$ during follicular and luteal phase, respectively $(\mathrm{P}$ $<0.01$ ). Mean serum 25OHD levels in healthy pregnant women were $26.5,30.1$ and $31.9 \mathrm{ng} / \mathrm{mL}$, at first, second and third trimester, respectively ( $\mathrm{P}<0.001)$. (Agudelo Zapata $\mathrm{Y}$ et al) Women are to educated about the importance of vitamin D supplementation and its association with infertility, polycystic ovary syndrome, obstetrical complications(N li,HM Wu et al 2017)

Community based studies conducted earlier have shown significant deficiency in the vitamin D levels in all age groups. (Table 5)

\section{Inference}

Early detection of vitamin D deficiency can prevent risk factors in pregnancy. New studies are warranted on this subject to elucidate the relationship of maternal vitamin D deficiency with skeletal, non-skeletal, autoimmune, cardiovascular disorders, diabetes and certain types of foetal imprinting (Souberbielle JC et al 2010)

Further monitoring of calcium and vitamin D levels in gestation along with iron and folic acid supplements to be given to the mother.Health education on intake of calcium and vitamin $\mathrm{D}$ to be given to the rural mothers. First trimester deficiency is often associated with miscarriages hence supplements to be started when the gestation is planned.

Table 5: Community-based studies on prevalence of Vitamin D deficiency in India (cited from Vitamin D deficiency in India by Aprna et al) ${ }^{21,22-38}$

\begin{tabular}{|c|c|c|c|c|c|}
\hline S.No & Author, year of publication & Site of study & Sample size & Study participants & Prevalence $(\%)$ \\
\hline 1 & Suryanarayana et $\mathrm{al}^{22} 2018$ & Hyderabad, Urban & 298 & $\begin{array}{l}\geq 60 \text { yearsTotal } \\
\text { MenWomen }\end{array}$ & $\begin{array}{l}56.3 \\
57.2 \\
54.2\end{array}$ \\
\hline 2 & Kapil et $\mathrm{al}^{23} 2017$ & Shimla, himachal Pradesh & 626 & Children (6-18 years) & 93 \\
\hline 3 & Chowdhury et al ${ }^{24} 2017$ & Delhi & 960 & 6-30 months & 34.5 \\
\hline 4 & Srimani et al ${ }^{25} 2017$ & West Bengal & 222 & $\begin{array}{l}\text { Rural postmenopausal women (45- } \\
70 \text { years) }\end{array}$ & 51 \\
\hline 5 & Misra et $\mathrm{al}^{26} 2017$ & Ballabargh & 381 & Rural Women $(20-60)$ years & 90.8 \\
\hline 6 & Rattan et al ${ }^{27} 2016$ & Cuttack, Odisha & 3056 & $30-65$ years & 84.9 \\
\hline 7 & Gunjaliya et al ${ }^{28}, 2015$ & Ahmadabad, Gujarat & 444 & No specific age group & 93.3 \\
\hline 8 & Bachhel et al ${ }^{29} 2015$ & Punjab & 150 & $17-68$ years & 90 \\
\hline 9 & Tandon et $\mathrm{al}^{30} 2014$ & Jammu and Kashmir & 312 & Postmenopausal women & 53.4 \\
\hline 10 & Agarwal and Sharma ${ }^{31} 2013$ & Varanasi & 200 & Adults $\geq 50$ years & 58 \\
\hline 11 & Marwa et al $2011^{32}$ & Delhi & 1346 & Urban Adults $\geq 50$ & 91.2 \\
\hline 12 & Harinarayan et al ${ }^{38} 2011$ & Tripuati & 55 & Reproductive female age $20-35$ & 76.3 \\
\hline 13 & Sahu et al $2009^{33}$ & Barabanki & 139 & Rural Pregnant & 74 \\
\hline 14 & Paul et al $2008^{34}$ & Tirupati & 150 & Semi urban postmenopausal women & 50 \\
\hline 15 & Puri et al $2008^{35}$ & Delhi & 404 & Urban Female adeloscent & 90.8 \\
\hline 16 & Goswami et al $2008^{36}$ & Agota village, Delhi & 57 & Rural adults & 68.5 \\
\hline 17 & Vupputuri et al $2006^{37}$ & Delhi & 105 & Urban Adults & 94 \\
\hline 18 & Harinarayan $2005^{38}$ & Tripuati & 164 & Rural postmenopaural women & 82 \\
\hline
\end{tabular}

\section{Conflict of Interest}

No Conflict of Interest

\section{Sources of Support}

No Funding sources.

\section{Abbreviations}

$\mathrm{mmol} / \mathrm{L}$ (milli moles per litre)

Vitamin D - 25 hydroxycholicalciferol

\section{Funding}

Self-funding

\section{Disclaimers}

No Disclaimers

\section{Acknowledgements}

We sincerely acknowledge Ms.Indrani, Social Health Worker who helped in approaching the mothers participated in the study.

\section{Literature Cited}

[1] Agrawal NK, Sharma B. Prevalence of osteoporosis in otherwise healthy Indian males aged 50 years and above. Arch Osteoporos. 2013;8:116.

[2] Agudelo-Zapata et al. Serum 25-hydroxyvitamin D levels throughout pregnancy: a longitudinal study in healthy and preeclamptic pregnant women 7:5 698-707.

[3] Anne Marie Uwitoze, Mohammed S, Razzaque Role of Magnesium in Vitamin D activation and Function ; Journal of American Osteopathis Association March 2018 118(3)

[4] Aparna P, S Muthathal, Baridalyne NongkynrihandSanjeev Kumar Gupta Vitamin D deficiency in India J Family Med Prim Care. 2018 MarApr; 7(2): 324-330. doi: 10.4103/jfmpc.jfmpc_78_18 PMCID: PMC6060930 PMID: 30090772.

[5] Ates S, Sevket O, Ozcan P, Ozkal F, Kaya MO, Dane B. Vitamin D status in the first-trimester: effects of Vitamin 
D deficiency on pregnancy outcomes. Afri Health Sci. 2016;16(1): 36-43.

[6] Bachhel R, Singh NR, Sidhu JS. Prevalence of Vitamin D deficiency in North-West Punjab population: A crosssectional study. Int J Appl Basic Med Res. 2015;5:7-11.

[7] Baker, A.M., Haeri, S., Camargo, C.A.,Jr, Espinola, J.A. \&Stuebe, A.M. 2010, "A nested case-control study of midgestation vitamin $\mathrm{D}$ deficiency and risk of severe preeclampsia", The Journal of clinical endocrinology and metabolism, vol. 95, no. 11, pp. 5105-5109.

[8] Bodnar, L.M., Catov, J.M., Simhan, H.N., Holick, M.F., Powers, R.W. \& Roberts, J.M. 2007b, "Maternal vitamin $\mathrm{D}$ deficiency increases the risk of preeclampsia", The Journal of clinical endocrinology and metabolism, vol. 92, no. 9, pp. 3517-3522.

[9] Bonny Specker Vitamin D requirements during pregnancy Am J ClinNutr 2004;80(suppl):1740S-7S

[10] BrittevanWeert,,DenicevandenBerg,

JessicaHrudey,AdriëtteJ.J.M.Oostvogels Is first trimester vitamin status in nulliparous women associated with pregnancy related hypertensive disorders? http://dx.doi.org/10.1016/j.midw.2015.12.007

[11] ChihChien Sung, Min - TserLian, Kuo Chen Lu, Cjia Chao Wu; Role of Vitamin D in Insulin resistance: Journal of Biomedicine and Biotechnology (2012) Article ID: 634195. Doi:10.11.55/2012/634195

[12] Chowdhury R, Taneja S, Bhandari N, Sinha B, Upadhyay RP, Bhan MK, et al. Vitamin-D deficiency predicts infections in young North Indian children: A secondary data analysis. PLoS One. 2017;12:e0170509.

[13] Elvira Larque, Eva Moralo, Rosaura Lies, Jose E, Blanco Carnero; Maternal and Foetal Health implications of Vitamin D status during pregnancy. Ann. NeutrMetab 2018;72:179-192 Doi 10.1159/000487370

[14] Goswami R, Kochupillai N, Gupta N, Goswami D, Singh $\mathrm{N}$, Dudha A, et al. Presence of $25(\mathrm{OH}) \mathrm{D}$ deficiency in a rural North Indian village despite abundant sunshine. J Assoc Physicians India. 2008;56:755-7.

[15] Gunjaliya A, Patil R, Vaza J, Patel H, Maniyar A. Prevalence of Vitamin D deficiency in higher socioeconomical class of Ahemdabad, Gujarat, India. Int J Med Sci Public Health. 2015;4:617-20.

[16] Harinarayan CV. Prevalence of Vitamin D insufficiency in postmenopausal South Indian women. Osteoporos Int. 2005;16:397-402.

[17] Kamal AS shoumer A, Thamer M Al Essa, Is there a relationship between vitamin with Insulin resistance and diabetes Mellitus. World J Diabetes 2015 Jul 25 6(8):1057-1064 PMID:26240702, PMC 451444.

[18] Kapil U, Pandey RM, Goswami R, Sharma B, Sharma N, Ramakrishnan L, et al. Prevalence of Vitamin D deficiency and associated risk factors among children residing at high altitude in Shimla district, Himachal Pradesh, India. Indian J EndocrinolMetab. 2017;21:17883.

[19] Lawlor DA, Wills AK, Fraser A, Sayers A, Fraser WD, et al. (2013) Association of maternal vitamin D status during pregnancy with bone-mineral content in offspring: a prospective cohort study. Lancet 381: 2176-2183. doi: 10.1016/S0140-6736(12)62203-X PMID: 23518316

[20] Li N, HM Wu, F Hang, YS Zhang et al Women with recurrent spontaneous abortion have decreased $25(\mathrm{OH})$ vitamin D and VDR at the foetal maternal interface Braz
J Med Bio Res.2017;50 (11): e 6527 Doi:10.1590/1414431X20176527 PMCID:5597287

[21] Liu NQ, Hewison M: Vitamin D, the placenta and pregnancy. Arch BiochemBiophys 2012; 523: 37-47.

[22] Marwaha RK, Tandon N, Garg MK, Kanwar R, Narang A, Sastry A, et al. Vitamin D status in healthy Indians aged 50 years and above. J Assoc Physicians India. 2011;59:706-9.

[23] Megan L. Mulligan, BA et al Implications of vitamin D deficiency in pregnancy and lactation: Am J Obstet Gynecol. 2010 May ; 202(5): 429.e1-429.e9. doi:10.1016/j.ajog.2009.09.002

[24] Misra P, Srivastava R, Misra A, Kant S, Kardam P, Vikram NK, et al. Vitamin D status of adult females residing in Ballabgarh health and demographic surveillance system: A community-based study. Indian J Public Health. 2017;61:194-8.

[25] Paul TV, Thomas N, Seshadri MS, Oommen R, Jose A, Mahendri NV, et al. Prevalence of osteoporosis in ambulatory postmenopausal women from a semiurban region in Southern India: Relationship to calcium nutrition and Vitamin D status. EndocrPract. 2008;14:665-71.[PubMed] [Google Scholar]

[26] Puri S, Marwaha RK, Agarwal N, Tandon N, Agarwal R, Grewal K, et al. Vitamin D status of apparently healthy schoolgirls from two different socioeconomic strata in Delhi: Relation to nutrition and lifestyle. $\mathrm{Br} \mathrm{J}$ Nutr. 2008;99:876-82.

[27] Rattan R, Sahoo D, Mahapatra S. Prevalence of Vitamin $\mathrm{D}$ deficiency in adults in the coastal regions of Odisha, India. IOSR J Pharm Biol Sci. 2016;11:49-52.

[28] Sahu M, Bhatia V, Aggarwal A, Rawat V, Saxena P, Pandey A, et al. Vitamin D deficiency in rural girls and pregnant women despite abundant sunshine in Northern India. ClinEndocrinol (Oxf) 2009;70:680-4.

[29] Shin JS, Choi MY, Longtine MS, Nelson DM: Vitamin D effects on pregnancy and the placenta. Placenta 2010; 31: $1027-1034$

[30] Souberbielle JC, Body JJ, Lappe JM, Plebani M, Shoenfeld Y, Wang TJ, et al. Vitamin D and musculoskeletal health, cardiovascular disease, autoimmunity and cancer: recommendations for clinical practice. Autoimmun Rev. 2010; 9:709-15.

[31] Specker B: Vitamin D requirements during pregnancy. Am J ClinNutr 2004; 80: 1740S- 1747S.

[32] Srimani S, Saha I, Chaudhuri D. Prevalence and association of metabolic syndrome and Vitamin D deficiency among postmenopausal women in a rural block of West Bengal, India. PLoS One. 2017;12:e0188331.

[33] Suryanarayana P, Arlappa N, SaiSanthosh V, Balakrishna N, Lakshmi Rajkumar P, Prasad U, et al. Prevalence of Vitamin D deficiency and its associated factors among the urban elderly population in Hyderabad metropolitan city, South India. Ann Hum Biol. 2018;45:133-9.

[34] Tandon VR, Sharma S, Mahajan S, Raina K, Mahajan A, Khajuria V, et al. Prevalence of Vitamin D deficiency among Indian menopausal women and its correlation with diabetes: A first Indian cross sectional data. J Midlife Health. 2014;5:121-5.

[35] Thomas SDC, Fudge AN, Whiting M, et al. The correlation between third-trimester maternal and 
newborn-serum 25-hydroxy-vitamin D in a selected South Australian group of newborn samples. BMJ Open 2011;1:e000236.doi:10.1136/bmjopen-2011-000236

[36] Vupputuri MR, Goswami R, Gupta N, Ray D, Tandon N, Kumar N, et al. Prevalence and functional significance of 25-hydroxyvitamin D deficiency and Vitamin D receptor gene polymorphisms in Asian Indians. Am J ClinNutr. 2006;83:1411-9.
[37] Widdowson EM. Changes in body composition during growth. In: Davi JA, Dobbings J, eds. scientific foundations of pediatrics. London: Wm Heinemann Medical Books, 1981:330-42.

[38] Xiao J-P, Zang J, Pei J-J, Xu F, Zhu Y, Liao X-P (2015) Low Maternal Vitamin D Status during the Second Trimester of Pregnancy: A Cross-Sectional Study in Wuxi, China. PLoS ONE 10(2): e0117748.doi:10.1371/journal.pone.0117748 